\title{
Third National Workshop on Lichens: over fifteen years of progress in lichen research in Sri Lanka
}

\author{
Siril Wijesundara ${ }^{1}$ and Veranja Karunaratne ${ }^{2^{*}}$ \\ ${ }^{1}$ Department of National Botanic Gardens, Peradeniya. \\ ${ }^{2}$ Department of Chemistry, Faculty of Science, University of Peradeniya, Peradeniya.
}

Although Sri Lanka is one of the biodiversity hotspots in the world, science is far behind in the description of lower plants when compared to the flowering plants. Lichens are one of such lower group of organisms. G.H.K. Thwaites, superintendent and later the Director of the Royal Botanic Gardens at Peradeniya, made the first collections of lichens in the central highlands of Sri Lanka between 1849 and 1880. Later, Alston (1926 - 1931), Kurokawa and Mineta (1973), Hale (1976 1978), Brunnbauer (1983 - 1987) and Moberg (1987) made collections and described lichens of Sri Lanka. In 1999 during the first ever nationally organized workshop on lichens organized by the University of Peradeniya and the National Botanic Gardens, it was established that although the number of lichens described up until then was less than 900 species, the real number might be in excess of 2000.

Research on lichen chemistry and taxonomy, which began in earnest after the first workshop particularly at the University of Peradeniya, the National Botanic Gardens and the University of Sri Jayewardenepura produced many publications and six $\mathrm{PhD}$ level research studies, three each in lichen chemistry and taxonomy. These studies on Sri Lankan lichens revealed that in contrast to higher plants (Bandara et al., 1990) they produce many biologically active secondary metabolites found only in lichens (Kathirgamanathar et al., 2006; Thadhani et al., 2011), and also described a number of lichen species new to science (Orange et al., 2001; Jayalal et al., 2012; Weerakoon et al., 2012). Importantly, the National Science Foundation of Sri Lanka provided pivotal financial support to the First National Lichen
Workshop and subsequent research efforts through five major research grants awarded to the Universities of Peradeniya, Sri Jayewardenepura and the National Botanic Gardens.

The rapid increase in population in Sri Lanka to 20 million (2012 census) with a density of $323 / \mathrm{km}^{2}$ has led to a huge expansion of urban areas, which has increased atmospheric pollution and encroachment of natural habitats as the demand for land has increased. There is now an urgency to enumerate the biodiversity of lichens of this tropical island with its many endemic species (as conservation of species diversity depends on their identification), and to explore the biological activities of their secondary metabolites.

As the latest activity in lichen research spanning over 15 years, the Third National Lichen Workshop was held from the $5^{\text {th }}-7^{\text {th }}$ March, 2015 at the Peradeniya Botanic Gardens. It was facilitated by a leading international team of lichenologists including Dr Pat Wolseley of the Natural History Museum, London, UK, Dr Andre Aptroot of the ABL Herbarium, The Netherlands, Prof. Marcela Cáceres of the Federal University of Sergipe, Brazil and Dr Gothamie Weerakoon, a scientific affiliate of the Field Museum of Chicago, USA, and other local resource persons including Dr Haris Peramunugama, Director General, Royal Botanic Gardens, Peradeniya, Prof. Veranja Karunaratne of the University of Peradeniya, Dr Siril Wijesundara, former Director General of the Department of Royal Botanic Gardens and Dr Udeni Jayalal, University of Sabaragamuwa. Importantly, both Dr Gothamie Weerakoon and Dr Udeni

*Corresponding author (veranjak@slintec.lk) 
Jayalal obtained their PhDs from the research activities, which began after the first lichen workshop. More than forty participants from different institutes including Universities, Research Institutes and other government organizations attended the workshop.

As an outcome of the third national workshop, a major research activity culminating in a comprehensive lichen survey of Sri Lanka is to be launched. The proposed research programme will explore and document the lichen flora of Sri Lanka in different ecosystems including 22 National Parks, 4 Botanic Gardens, 5 Forest Reserves, the coastal area and home gardens as a first step towards describing the entire lichen flora of the country. It will also accomplish the urgent task of making a lichen checklist of Sri Lanka.

The proposed volume "Lichen Flora of Sri Lanka" will ultimately be a major source of information about lichens for those who are interested in the study of lichens. Furthermore, it is envisaged that it will create the infrastructure at the Botanical Gardens and wildlife conservation sectors facilitating the incorporation of lichens into the National Biodiversity Strategy and Action Plan. The results of the project will be used to popularize lichen studies in schools and other institutes and to emphasize their importance. The study will further identify secondary metabolites of lichens active against different biological agents. They will be used for further investigations with a view to establishing their medicinal potential.

\section{REFERENCES}

1. Bandara B.M.R., Hewege C.M., Jayamanne D.H.L.W., Karunaratne V., Adikaram N.K.B., Bandara K.A.N.P., Pinto M.R.M. \& Wijesundara D.S.A. (1990). Biological activity of some steam distillates from ten species of Rutaceae plants. Journal of the National Science Council of Sri Lanka 18(1): $71-77$.

2. Jayalal R.G.U., Wolseley P.A., Gueidan C., Aptroot A., Wijesundara D.S.A. \& Karunaratne V. (2012). Anzia mahaeliyensis and Anzia flavotenuis, two new species from Sri Lanka. The Lichenologist 44(3): 381 - 389. DOI: http://dx.doi.org/10.1017/S0024282911000946

3. Kathirgamanathar S., Ratnasooriya W.D., Baekstrom P., Andersen R.J. \& Karunaratne V. (2006). Chemistry and bioactivity of Physciaceae lichens Pyxine consocians and Heterodermia leucomelos. Pharmaceutical Biology (Formerly International Journal of Pharmacognosy) 44(3): $217-220$.

DOI: http://dx.doi.org/10.1080/13880200600686624

4. Orange A., Wolseley P., Karunaratne V. \& Bombuwela K. (2001). Two leprarioid lichens new to Sri Lanka. Bibliotheca Lichenologica 78: 327 - 333.

5. Thadhani V., Choudhary I.M., Ali S., Omar I., Siddique H. \& Karunaratne V. (2011). Antioxidant activity of some lichen metabolites. Natural Products Research 25(19): $1827-1837$. DOI: http://dx.doi.org/10.1080/14786419.2010.529546

6. Weerakoon G., Wijeyaratne S.C., Wolseley P.A., Plata E.R., Lücking R. \& Lumbsch H.T. (2012). Six new species of Graphidaceae from Sri Lanka. The Bryologist 115(1): $74-83$.

DOI: http://dx.doi.org/10.1639/0007-2745-115.1.74 